\title{
Artykuey
}

KLIO. Czasopismo poświęcone dziejom Polski i powszechnym

PL ISSN 1643-8191, t. 22 (3)/2012, s. 39-58

\section{Agnieszka Pawłowska}

(Toruń)

\section{Program wzmocnienia wladzy w kregach stronnictwa prokrólewskiego w czasie rokoszu sandomierskiego 1605-1609}

U

strój polityczny nowożytnej Rzeczpospolitej, popularnie zwany „demokracją szlachecką”, trafniej określany jako monarchia mixta, kształtował się na przestrzeni wieków, a jego zaczątkiem były wydane przez władców już w średniowieczu przywileje dla ogółu stanu rycerskiego. System państwowy, na który składały się trzy rywalizujące o władzę w państwie siły polityczne: król, magnateria i szlachta, ukształtował się w okresie od śmierci Zygmunta Augusta do zakończenia rokoszu sandomierskiego ${ }^{1}$, by w drugiej połowie XVII wieku ulec wypaczeniom, a w XVIII wieku degrengoladzie.

U schyłku XVI wieku coraz częściej rozlegały się głosy mówiące o potrzebie reformy sposobu sejmowania, stworzeniu licznej, stałej armii oraz zapewnieniu skarbowi stałych dochodów przez regularnie uchwalane podatki. Reform tych nie udało się wprowadzić w życie, kiedy tron polski objął Zygmunt III Waza. Sejmy przełomu XVI i XVII wieku, rozchodzące się bez uchwał lub uchwalające konstytucje w mało istotnych sprawach, powodowały wzrost niezadowolenia szlachty, co łączyło się z brakiem popularności króla² w szlachec-

${ }^{1}$ M. Markiewicz, Historia Polski 1492-1795, Kraków 2002, s. 31.

2 Brak popularności monarchy, oprócz powodów typowo irracjonalnych (z niechęcią wypowiadano się na temat zainteresowań Zygmunta III: gry w piłkę, malarstwa, gry na klawesynie, złotnictwa, jako mało „rycerskich”. Szeroko powtarzano i komentowano słowa Jana Zamoyskiego, 
kim społeczeństwie. Władca dostrzegał ograniczenia uprawnień królewskich. Zarówno Zygmunt III, jak i jego stronnictwo widziało w okrzepnięciu izby poselskiej w takiej formie, jaką reprezentowała u progu XVII wieku, przy rosnącej roli sejmików ${ }^{3}$, zjawisko niebezpieczne dla sprawnego funkcjonowania państwa i starało się mu przeciwdziałać. W ten sposób konflikt między poddanymi a królem zaostrzał się, a dodatkowo podsycany przez opozycyjnych mu, mających poważanie wśród szlachty, magnatów (na czele z kanclerzem i hetmanem wielkim koronnym Janem Zamoyskim), musiał doprowadzić prędzej czy później do wybuchu otwartego niezadowolenia.

Rokosz sandomierski jest zatem momentem bardzo istotnym, gdy mowa o przemianach ustroju Rzeczpospolitej. Jednak w przeciwieństwie do ruchu egzekucji praw i dóbr z czasów Zygmunta Augusta, szlachecka opozycja nie była w stanie wykreować jednego, spójnego i możliwego do realizacji programu reform politycznych państwa. Do słusznego wniosku doszedł Janusz Byliński w artykule Rokoszowe koncepcje reformy państwa (1606-1608) ${ }^{4}$, że zakrojony na szeroką skalę ruch rokoszowy nie przyniósł jakichkolwiek realnych i ważnych pomysłów reformatorskich w duchu demokracji szlacheckiej, a jedną z ważniejszych przyczyn tego stanu rzeczy była rozbieżność dążeń osób zaangażowanych w rokosz:

dysydenci zabiegali przede wszystkim o konfederację warszawską, była ona dla nich celem najważniejszym. Katolicy byli jej przeciwni, ale ulegali fałszywym argumentom Zebrzydowskiego i jego obietnicom odsłonięcia jakichś ważnych i groźnych tajemnic. Szlachta widziała swe interesy w walce z ma-

który miał określić władcę jako „nieme monstrum ze Szwecji”), miał niestety także pewne racjonalne przyczyny. Król rzeczywiście chętnie otaczał się gronem kontrreformatorów, nie ingerował w sprawach tumultów religijnych, a przy mianowaniu urzędników i senatorów stosował kryterium religijne, co nie mogło podobać się różnowiercom. Oskarżano go również o uległość wobec Rzymu i uleganie obcym wpływom (w szczególności jezuitom), co widoczne będzie zwłaszcza w czasie sejmu 1606 roku. Szerzej o zainteresowaniach władcy: W. Leitsch, Das Leben am Hof König Sigismunds III. von Polen, band II, Wien 2009, s. 818 i 857-860; o zarzutach wobec Zygmunta III: H. Wisner, Zygmunt III Waza, Wrocław 1991, s. 84-90.

3 O procesie obniżenia rangi i powagi sejmu, przy jednoczesnym wzroście roli sejmików: U. Augustyniak, Wazowie i „królowie rodacy”. Studium wtadzy królewskiej w Rzeczypospolitej XVII wieku, Warszawa 1999, s. 11-14.

${ }^{4}$ J. Byliński, Rokoszowe koncepcje reformy państwa (1606-1608), [w:] Studia historyczno-prawne. Ksiegga poświęcona pamięci Profesora Jana Seredyki, red. W. Kaczorowski, Opole 2008, s. 59-106. 
gnatami, co było pewnym paradoksem, gdyż magnaci zapewniali jej utrzymanie na swych dworach ${ }^{5}$.

Rokoszanie za bardzo byli bowiem pochłonięci walką z królem, by stworzyć pozytywny program naprawy państwa. Czy jednak z równie dużym pustkowiem pomystów w dziedzinie reformy państwa mamy do czynienia w stronnictwie zwolenników Zygmunta III ? Czy obóz prokrólewski, w obliczu krytyki i oskarżeń, zdolny był tylko do odpierania zarzutów, czy może zaproponował szerszy plan naprawy Rzeczpospolitej? A jeśli tak, to czy był to plan realny, możliwy do przyjęcia przez ogół szlachty? Na te pytania postaram się odpowiedzieć w tym artykule.

Najpełniej jak do tej pory stronnictwo prokrólewskie doby rokoszu sandomierskiego scharakteryzował Stanisław Cynarski ${ }^{6}$. Krąg najbliższych współpracowników Zygmunt III tworzył przez umiejętną politykę nominacyjną ${ }^{7}$, a kluczem do uzyskania królewskiego zaufania i idących za tym nadań było niewątpliwie sprzyjanie królewskim planom i wyrażanie dla nich poparcia oraz podobne do Zygmunta III postrzeganie roli króla w Rzeczpospolitej. Dlatego nie wszyscy członkowie stronnictwa prokrólewskiego cieszyli się równą sympatią władcy ${ }^{8}$. Przed przejściem do analizy poszczególnych koncepcji wzmoc-

${ }^{5}$ Ibidem, s. 105. Brak konstruktywnego programu opozycji w okresie rokoszu sandomierskiego podkreśla także Ewa Dubas-Urwanowicz, porównując stronnictwa opozycyjne i prokrólewskie w czasie zjazdu lwowskiego w 1537 roku i doby rokoszu sandomierskiego; E. DubasUrwanowicz, Stronnicy królewscy i opozycjoniści wobec monarchy w dobie zjazdu lwowskiego i rokoszu sandomierskiego. Próba porównania, [w:] Król a prawo stanów do oporu, red. M. Markiewicz, E. Opaliński, R. Skowron, Kraków 2010, s. 120.

${ }^{6}$ S. Cynarski, Stronnictwo królewskie w dobie rokoszu Zebrzydowskiego (próba charakterystyki), „Małopolskie Studia Historyczne”, 1965, r. 8, z. 3/4, s. 3-24.

7 Ibidem, s. 4-5; E. Dubas-Urwanowicz, Stronnicy królewscy i opozycjoniści..., s. 110-112.

8 Znamienne są tu drogi kariery dwóch osób zaliczonych przez S. Cynarskiego do stronnictwa prokrólewskiego - kasztelana sieradzkiego Aleksandra Koniecpolskiego i hetmana koronnego polnego Stanisława Żółkiewskiego. Konsekwentnie potępiający rokoszan Koniecpolski, zwalczający nastroje rokoszańskie w ziemi sieradzkiej, a później, w czasie bitwy pod Guzowem, czuwający nad bezpieczeństwem króla i całego jego szyku, został przez Zygmunta III hojnie nagrodzony - dla siebie uzyskał tytuł wojewody sieradzkiego, zaś dla swojego syna Stanisława starostwo wieluńskie. Drugie z nadań stało się zresztą źródłem drwin i oburzenia szlachty, bo Stanisław był wówczas niepełnoletni. O antyrokoszowej działalności Aleksandra Koniecpolskiego: S. Łubieński, Droga do Szwecji Zygmunta III, króla polskiego i szwedzkiego, w 1593 roku, przeł. A. B. Jocher; Rozruchy domowe w Polsce 1606-1608, przeł. S. Szczygieł, wyd. J. Byliński i W. Kaczorowski, Opole 2009, s. 76, 129, 151; E. Opaliński, Postawa polityczna szlachty województwa sieradzkiego w latach 1587-1648, „Odrodzenie i Reformacja w Polsce” 1981, t. 26, s. 55-58; o otrzymanych od Zygmunta III nada- 
nienia władzy królewskiej formułowanych w czasie rokoszu sandomierskiego, należy wyraźnie oddzielić regalistów od monarchistów w kręgu Zygmunta III. Monarchiści byli zwolennikami silnej władzy monarszej, natomiast regaliści to polityczni stronnicy króla w konkretnie wytworzonej sytuacji politycznej", często przy tym uznawani za karierowiczów, koniunkturalnie wspierających władcę $^{10}$ (co zresztą wytykać im będą sami rokoszanie). Pod pojęciem regalizmu można dostrzec cały wachlarz stanowisk i poglądów, a chęć wzmocnienia władzy królewskiej czy nawet dalej - przebudowy kraju w duchu absolutystycznym - to tylko jeden z nich ${ }^{11}$. Regaliści doby rokoszu sandomierskiego opowiedzieli się, co oczywiste, po stronie Zygmunta III, próbowali studzić zapały zrewoltowanej szlachty na sejmikach i sejmach 1606 i 1607 roku, bronili majestatu królewskiego nie tyle nawet ze względu na konkretną osobę, co ze względu na powagę sprawowanego urzędu, a gdy to nie dało efektów - przystąpili do zbrojnej rozprawy z rokoszanami. Jednak to spod pióra monarchistów, na ich zlecenie, w kręgu bliskich im współpracowników wyszły koncepcje wzmocnienia władzy królewskiej, pojawiające się w publicystyce politycznej czasów rokoszu sandomierskiego.

niach: H. Kotarski, Koniecpolski Aleksander, [w:] Polski Stownik Biograficzny [dalej: PSB], 1967-1968, t. 13, s. 511-512; L. Podhorodecki, Hetman Stanistaw Koniecpolski, Warszawa 2011, s. 19, 22; Z. Wielebska, Powstanie majątku Stanistawa Koniecpolskiego (1591-1646), hetmana wielkiego koronnego, „Studia Historyczne” 1981, R. 24, z. 4, s. 550-551. Potępiający zbrojne wystąpienie przeciwko władcy, jednak wcześniej będący wiernym stronnikiem antagonisty Zygmunta III, Jana Zamoyskiego, upatrujący załagodzenia konfliktu w państwie na drodze sejmowej, uznający przy tym słuszność części postulatów rokoszan, a dodatkowo spowinowacony z Mikołajem Zebrzydowskim, hetman polny Stanisław Żółkiewski cieszył się bardzo ograniczonym zaufaniem króla. Choć Żółkiewski zwycięsko wyszedł z próby wierności i gromił rokoszan pod Guzowem, na upragnioną buławę wielką musiał czekać aż do 1618 roku; Votum [Stanisława Żółkiewskiego] na sejmie warszawskim 1607, [w:] Pisma Stanistawa Żótkiewskiego, wyd. A. Bielowski, Lwów 1861, s. 472; J. Besala, Stanistaw Żótkiewski, Warszawa 1988, s. 164-175.

9 J. Maciszewski, Sejm $1607 \mathrm{r}$. a zatamanie sięplanów reformy państwa, [w:] O naprawę Rzeczypospolitej XVII-XVIII w. Prace oflarowane Wtadystawowi Czaplińskiemu w 60 rocznice urodzin, red. J. Gierowski, A. Kersten, J. Maciszewski, Z. Wójcik, Warszawa 1965, s. 37.

${ }_{10}$ Szerzej o tym: A. Kersten, Problem wtadzy w Rzeczypospolitej czasu Wazów, [w:] O naprawę Rzeczypospolitej..., s. 28. Na zbytnie uproszczenie tego schematu zwrócił ostatnio uwagę Robert I. Frost, wychodząc z założenia, że sprowadzanie regalizmu do skali zwykłego karierowiczostwa uniemożliwia zrozumienie świata polityki epoki Wazów. R. I. Frost, Regaliści bez regalizmu? Dwór królewski w czasach Wazów, [w:] Dwór a kraj. Między centrum a peryferiami wtadzy, red. R. Skowron, Kraków 2003, s. 295-306.

11 R. I. Frost, Regaliści bez regalizmu..., s. 304. 
Kogo konkretnie można zaliczyć do grona monarchistów w otoczeniu Zygmunta III ? Z pewnością był nim marszałek wielki koronny Zygmunt Gonzaga Myszkowski ${ }^{12}$; starosta kruszwicki, a następnie referendarz (1606), podkanclerzy (1609) i kanclerz wielki koronny (1613) Feliks Kryski ${ }^{13}$; wojewoda poznański Hieronim Gostomski ${ }^{14}$ wraz z synem Janem ${ }^{15}$ i bratem, wojewodą podlaskim i mazowieckim, Tomaszem ${ }^{16}$; biskup łucki, a od 1607 roku biskup płocki Marcin Szyszkowski ${ }^{17}$; biskup przemyski, podkanclerzy (1605), a następnie kanclerz wielki koronny Maciej Pstrokoński ${ }^{18}$; marszałek nadworny Mikołaj Wolski ${ }^{19}$; sekretarz królewski, a następnie podkomorzy wielki koronny (1607) Andrzej Bobola ${ }^{20}$; nadworny kaznodzieja Zygmunta III Piotr Skar$\mathrm{ga}^{21}$. W Wielkim Księstwie Litewskim do stronnictwa prokrólewskiego zaliczyć można biskupa wileńskiego Benedykta Woynę, kanclerza litewskiego Lwa Sapiehę i hetmana polnego litewskiego Jana Karola Chodkiewicza, jednak zdecydowanym zwolennikiem wzmocnienia władzy królewskiej był przede wszystkim wojewoda wileński Mikołaj Krzysztof Radziwiłł „Sierotka”22.

Wszystkie osoby, zaliczone za S. Cynarskim i E. Dubas-Urwanowicz do grona monarchistów, będą oczywiście posiadały zróżnicowane poglądy na wzmocnienie władzy królewskiej, począwszy od wzorowania się na modelu „hiszpańskim” (Piotr Skarga), skończywszy na modelu „wschodnim” (Mikołaj Krzysztof Radziwiłł). Różne będą także propozycje przeprowadzenia reform w Rzeczpospolitej (jedni będą zwolennikami legalnej drogi parlamentarnej, dla drugich będzie ona nierealna do urzeczywistnienia).

Punktem wyjścia do wykrystalizowania się koncepcji wzmocnienia władzy w Rzeczpospolitej był przedrokoszowy sejm 1605 roku. W wysłanych zwyczajowo do senatorów literas deliberatorias nie znalazły się konkretne propozycje reform ustrojowych ${ }^{23}$, natomiast pewne propozycje w duchu wzmoc-

\footnotetext{
12 U. Augustyniak, Myszkowski Zygmunt, PSB 1977, t. 22, s. 404-407.

13 J. Maciszewski, Kryski Feliks, PSB 1970, t. 15, s. 482-485.

${ }_{14}$ K. Lepszy, Gostomski Hieronim, PSB 1959-60, t. 8, s. 364-366.

15 W. Dworzaczek, Gostomski Jan, PSB 1959-60, t. 8, s. 366-367.

16 S. Herbst, Gostomski Tomasz, PSB 1959-60, t. 8, s. 369.

17 K. Niesiecki, Herbarz Polski, wyd. J. N. Bobrowicz, t. 8, Lipsk 1841, s. 648-650.

${ }_{18}$ H. Kowalska, Pstrokoński Maciej, PSB 1986, t. 29, s. 265-271.

19 K. Niesiecki, Herbarz..., t. 9, Lipsk 1842, s. 406-407.

20 W. Dobrowolska, Bobola Andrzej, PSB 1936, t. 2, s. 153-155.

${ }^{21}$ J. Tazbir, Skarga Piotr, PSB 1997-1998, t. 38, s. 35-43.

22 S. Cynarski, Stronnictwo królewskie w dobie rokoszu Zebrzydowskiego..., s. 13-14.

${ }^{23}$ Zygmunt III zwracał głównie uwagę na niebezpieczeństwo grożące Rzeczypospolitej z ze-
} 
nienia pozycji króla i senatu przesłał Zygmuntowi III w odpowiedzi Maciej Pstrokoński. Biskup przemyski postulował przyznanie królowi prawa zwoływania pospolitego ruszenia zawsze, gdy wymagałaby tego potrzeba, ostateczne załatwienie kwestii kurateli pruskiej radził pozostawić tajnej radzie senatu, przedstawił także godzący w izbę poselską plan reformy sejmowania, według której rozstrzygający i ostateczny głos pozostawić miano senatowi ${ }^{24}$. Królewska instrukcja na sejmiki przedsejmowe - prawdopodobnie po to, aby nie dolewać oliwy do ognia w związku z krytycznym nastawieniem opozycji na czele z Janem Zamoyskim do władcy - nie zawierała żadnych postulatów reform ${ }^{25}$. Jałowe, nie wykraczające poza omówienie instrukcji królewskiej, były na sejmie wota przedstawicieli stronnictwa królewskiego. Jedynie Hieronim Gostomski podjął próbę wykazania, że szlachta powinna słuchać władcy zarówno w państwach, gdzie panują rządy absolutne, jak i w takich, gdzie non absolute dominabantur, stosując przy tym porównanie państwa do ciała ludzkiego ${ }^{26}$. Zalecał przy tym słuchanie "głowy” i posłuszeństwo, ale poza tą komparacją nie przedstawił żadnego programu czy nawet postulatu wzmocnienia państwa polskiego we wzmiankowanym przez siebie duchu. Brak precyzyjnie sformułowanego programu reform, przy jednoczesnym wielkim uporze opozycjonistów w kwestii - chociażby - uporządkowania spraw religijnych oraz braku chęci pogodzenia zwaśnionych stron przez poróżnionego z królem Jana Zamoyskiego, to powody, dla których sejm 1605 roku rozszedł się bez podjęcia uchwał.

Wydaje się też, że prawdziwa krecia robota, której skutkiem było rozejście się sejmu w 1605 roku z niczym, została wykonana na sejmiku bełskim. Osobiście zjawił się na nim Jan Zamoyski, a opracowana instrukcja dla posłów na sejm wyrażała poglądy hetmana, wykraczając daleko poza propozycje stronnictwa królewskiego przedstawione w legacji. Tzw. artykuły bełskie ustosunkowywały się zarówno do rzeczywistych planów królewskich, jak i odnosiły się do szerzących się wśród szlachty pogłosek ${ }^{27}$. Nie wnosiły w zasadzie nic kon-

wnątrz, dużo mówił o konieczności poparcia wojny inflanckiej, unikał jednak tematów spornych i drażliwych (reforma sejmowania, kwestia planowanego królewskiego małżeństwa z siostrą zmarłej żony, Konstancją Habsburżanką); Zygmunt III do Jana Karola Chodkiewicza, Kraków 4 XI 1604, Biblioteka Kórnicka PAN [dalej: Bibl. Kórn. PAN], sygn. 1539, k. 173-174; A. Strzelecki, Sejm z 1605 roku, Kraków 1921, s. 38.

${ }_{24}$ A. Strzelecki, Sejm z 1605 roku..., s. 38-39.

25 Ibidem, s. 42-47. Instrukcja zawierała same ogólniki i poruszała kwestie polityki zagranicznej.

${ }^{26}$ Ibidem, s. 98.

27 Instrukcyja Województwa Betskiego, Postom na Sejm Warszawski w roku 1605 przez Jego 
struktywnego i nie przedstawiały planów reform, a jedynie wyliczały niedomagania ustrojowe i krytykowały politykę Zygmunta III. Mimo tego artykuły bełskie, rozrzucone po kraju w odpisach, wpłynęły na przebieg następnych sejmików, a później stały się fundamentem artykułów sandomierskich ${ }^{28}$.

Dopiero śmierć kanclerza i hetmana wielkiego koronnego na początku czerwca 1605 roku i związane z tym osłabienie i dekompozycja stronnictwa opozycyjnie nastawionego w stosunku do władcy ${ }^{29}$ stały się motorem do wykrystalizowania się konkretniejszych planów wzmocnienia władzy w Rzeczpospolitej. Pod koniec 1605 roku Zygmunt III wraz ze swoim stronnictwem podjął decyzję o konieczności zwołania sejmu. Informacja o zwołaniu sejmu przez władcę dotarła do szlachty na początku następnego roku, wraz ze staranniej niż ostatnio przygotowaną instrukcją królewską na sejmiki przedsejmowe $^{30}$. Na początku poruszała ona problem konsekwencji rozejścia się poprzedniego sejmu bez podjęcia uchwał. Naraziło to kraj na niebezpieczeństwo zewnętrzne, a na zapłatę żołnierzy i upominki dla Tatarów przeznaczono resztę kwarty. Nie stanęło to jednak na przeszkodzie temu, by „garścią ludzi prawie" odnieść zwycięstwo nad Szwedami w bitwie pod Kircholmem oraz sfor-

Moi Pana Zamojskiego Kanclerza i Hetmana Koronnego pisana, [w:] A. Sokołowski, Przed rokoszem. Studium historyczne za czasów Zygmunta III, „Rozprawy i Sprawozdania z Posiedzeń Wydziału Historyczno-Filozoficznego Akademii Umiejętności”, t. 25, Kraków 1882, s. 201-212. Instrukcja, ujęta w 35 punktów, domagała się, między innymi, potwierdzenia niezmienności prawa wolnej elekcji, nakładała na króla obowiązek obrony granic Rzeczpospolitej, ponoszenia kosztów legacji i upominków tatarskich, zabraniała tworzyć nowe urzędy oraz przyjmować przez szlachtę cudzoziemskie tytuły. Zygmunt III miał niezwłocznie rozdać wakancje i ukarać sprawców tumultów religijnych. Winą za swawolę żołnierską obarczono przepisy ograniczające władzę hetmańską. Odnosząc się do planowanego małżeństwa królewskiego („co się między ludźmi trzęsie”), zdecydowanie mu się sprzeciwiała. Potępiono także popieranie Dymitra Samozwańca i wyprawę króla do Szwecji.

28 S. Grzybowski, Jan Zamoyski, Warszawa 1994, s. 277-278; J. Byliński, Rokoszowe koncepcje reformy państwa (1606-1608)..., s. 85-86.

${ }_{29}$ Rozpad stronnictwa skupionego wokół kanclerza przeanalizowała Violetta Urbaniak; V. Urbaniak, Zamoyszczycy bez Zamoyskiego. Studium dekompozycji ugrupowania politycznego, Warszawa 1995. Okazało się, że po śmierci Zamoyskiego nie było osoby obdarzonej równie dużym autorytetem i charyzmą, która byłaby zdolna stanąć na czele stronnictwa i utrzymać je w dotychczasowym kształcie.

30 Treść instrukcji przytaczam na podstawie treści legacji posła królewskiego, Wacława Leszczyńskiego, na sejmik przedsejmowy województw poznańskiego i kaliskiego w Środzie; Akta sejmikowe województw poznańskiego i kaliskiego, t. 1: (1572-1632), cz. 1: (1572-1616), wyd. W. Dworzaczek, Poznań 1957, s. 269-275. Omówienie instrukcji: W. Sobieski, Pamiętny sejm, Warszawa 1913, s. 31-34; J. Maciszewski, Wojna domowa w Polsce (1606-1609). Studium z dziejów walki przeciw kontrreformacji, cz. 1: Od Stężycy do Janowca, Wrocław 1960, s. 105. 
mować obronę przed kolejnym najściem Tatarów. Król jednak zdecydowanie podkreślał, że środki są niewystarczające i ,gruntowniejszego co brać przed się jużby kiedy należało, jeśliż w majętnościach, w zdrowiu i w sławie, cali od jego najazdów zostać chcemy" ${ }^{31}$. Należało także coś uradzić, aby umocnić swoją pozycję w Inflantach, bo wróg na pewno zaatakuje ponownie. Wychodząc od sytuacji zewnętrznej państwa, instrukcja zgrabnie przechodziła do kierunków polityki i reform, które miały stać się remedium na niebezpieczeństwo kraju. Rozwiązania wojny ze Szwecją radzono szukać u jej źródła - wyprawa mająca na celu przywrócenie tronu szwedzkiego Zygmuntowi III nie tylko spowodowałaby zakończenie konfliktu, ale i podniosła prestiż Królestwa Polskiego ${ }^{32}$. Władca wskazywał zatem, że kontynuacja wojny z Karolem Sudermańskim będzie miała szczęśliwe dla Rzeczpospolitej zakończenie i tylko wtedy należycie zabezpieczy kraj przed szwedzkimi najazdami, gdy Zygmunt III uda się, za pozwoleniem stanów, do Szwecji w celu odzyskania dziedzicznej korony. Stanie się to możliwe tylko wówczas, gdy na wojsko będą przeznaczone stałe środki pieniężne, których „by się bez sejmu, kiedy gwałt, dosięgać mogło”33. Utworzenie stałej armii to jedna z najpilniejszych potrzeb Rzeczpospolitej i jeden z najważniejszych punktów instrukcji. Stąd król żąda, aby postulat ten uchwalono przed innymi kwestiami, jako sprawę „najpilniejszą” i „najgwałtowniejszą”, a posłowie nie odjeżdżali z sejmu bez podjęcia tej ważnej uchwały. Gwarancją bezpieczeństwa państwa miałoby też być przymierze zawarte z carem Dymitrem oraz ostateczne uregulowanie kwestii kurateli pruskiej.

Po omówieniu kwestii związanych z polityką zagraniczną, instrukcja zwracała uwagę na sprawy wewnętrzne, największe niebezpieczeństwo widząc w prywatnych kłótniach szlachty, będących często przyczyną łamania praw, gwałtów i najazdów czynionych przez zaciągniętych przez zwaśnione strony żołnierzy.

O najistotniejszym punkcie królewskiej propozycji legacja wspominała raz jeszcze na końcu. Zygmunt III nalegał, aby szlachta zobowiązała swoich przedstawicieli do ścisłego trzymania się propozycji od tronu, nie poruszania innych, mniej istotnych zdaniem króla, kwestii oraz by posłowie nie rozjechali się do domów bez podjęcia uchwał dotyczących podatków na wojsko ${ }^{34}$.

31 Akta sejmikowe województw poznańskiego i kaliskiego..., t. 1, cz. 1, s. 271.

32 Ibidem, s. 272.

33 Ibidem.

34 „Toż i pp. posłom swym zalećcie, i tak to poruczcie, aby nie same tylko sześć niedziel na sejmie zawierali, ale co jest przełożono od J.K.M. to, co wszystko wszytkę R.P. i jej bezpieczeństwo 
$\mathrm{Z}$ treści instrukcji widać wyraźnie, że przedstawia ona bardzo delikatnie niektóre postulaty mogące posłużyć wzmocnieniu władzy królewskiej. Propozycja od tronu ani słowem nie wspominała koncepcji, o które opozycjoniści oskarżali monarchę, jak chociażby planów koronacji królewicza Władysława za życia Zygmunta III. Ale - choć w zawoalowanej formie - chęć wzmocnienia pozycji monarchy jest $\mathrm{w}$ instrukcji wyraźnie widoczna w postaci dalekosiężnego planu stworzenia stałych podatków, niezależnych od decyzji szlachty, a przeznaczonych na utrzymanie stałej armii; pojawia się też kwestia wyprawy króla do Szwecji w celu odzyskania tronu - to wszystko, zdaniem Jaremy Maciszewskiego, oznaczało mocniejsze wciągnięcie Rzeczpospolitej do dynastycznych rozgrywek Zygmunta III, ponadto dawałoby mu swobodniejszą rękę w Polsce ${ }^{35}$. Oczywiście instrukcja, która nie poruszała co rusz powtarzanych przez szlachtę na sejmikach postulatów, musiała zaognić i tak już napiętą sytuację w kraju.

Rolę komentarza do instrukcji królewskiej spełniło pismo Votum szlachcica polskiego pisane na sejmiki i sejm roku pańskiego $1606^{36}$, które niewątpliwie wyszło z kręgu stronnictwa królewskiego. Votum... najwięcej miejsca poświęca niebezpieczeństwu zewnętrznemu Rzeczpospolitej, zwracając uwagę na zagrożenie ze strony Tatarów i Turków, Węgrów, Szwedów w Inflantach, podkreślając, że pokój z Moskwą to również nic pewnego. Analizując tekst, należy zwrócić uwagę na dwie sprawy, które zarówno w instrukcji, jak i w Votum... odgrywają rolę priorytetową - kwestia obrony kraju oraz reforma sejmowania. Krytykując dwa dotychczasowe sposoby obrony kraju - pospolite ruszenie i doraźne pobory na zapłatę żołnierza - autor pisma postuluje dać posłom na sejm absolutum potestatem ${ }^{37} \mathrm{w}$ sprawie zorganizowania stałej armii. W każdym województwie istniałby specjalnie przeznaczony na te cele skarbiec, a pieniądze spływałyby z opodatkowania wszystkich stanów, nie wyłączając przy tym duchowieństwa. Daleko posunięta krytyka sejmu w Votum... przedstawia tę instytucję Rzeczpospolitej jako niesprawną przez rozpolitykowanie, niezgodną

zachodzi, odprawowali i stanowili, a nie zwracali się bez zawarcia statecznego potrzeb[n]y obrony z sejmu przyszłego i aby nie [na] zapieranie, nie na protestacyje [...] patrzali”; ibidem, s. 274.

35 J. Maciszewski, Wojna domowa w Polsce..., s. 105.

36 Treść Votum..., [w:] Pisma polityczne z czasów rokoszu Zebrzydowskiego 1606-1608, t. 2: Proza, wydał J. Czubek, Kraków 1918, s. 221-231, jego omówienie: W. Sobieski, Pamiętny sejm..., s. 35-37; S. Cynarski, Stronnictwo królewskie w dobie rokoszu Zebrzydowskiego...., s. 17-18; J. Maciszewski, Wojna domowa w Polsce..., s. 106-107.

37 Votum..., [w:] Pisma polityczne..., t. 2, s. 227. 
i przekupną ${ }^{38}$, będącą przy tym pośmiewiskiem na zachodzie Europy ${ }^{39}$. Autor wykazuje nieskuteczność dotychczasowej metody sejmowania, przez co sejmy rozchodzą się z niczym. Radą na to jest wprowadzenie systemu głosowania większością głosów, jak np. w Wenecji, czyli całkowita likwidacja liberum veto, lub likwidacja... samego sejmu. Co prawda Votum... nie proponuje szlachcie wprost likwidacji tej najważniejszej instytucji demokratycznej Rzeczpospolitej, ale autor wyraźnie wzywa do tego, ubolewając:

Porachujcie WM., co sejmy kosztują. Patrzcie na niewczasy wasze, które tam miewacie. Uważcież konkluzye ich. Piórko dalej nie chce. Ach, rzecz niewypowiedzianego żalu pełna! Byście WM. to dać raczyli na obronę, co WM. sejmy kosztują, nieśmiertelną sprawę zostawilibyście potomstwu waszemu $^{40}$.

Nie można zatem zgodzić się z J. Maciszewskim, że Votum... nie wykazywało, w przeciwieństwie do instrukcji królewskiej, tendencji likwidatorskich w stosunku do sejmu ${ }^{41}$, bynajmniej, wykazywało je w o wiele większym stopniu! Dokładna i szczegółowa analiza wykazuje wręcz, że Votum... w obu sprawach - powołania stałej armii (znamienne absolutum potestatem, absolutna władza posłów w tej kwestii) oraz reformy sejmowania - wykraczało śmiałością rozwiązań poza instrukcję królewską.

Wota senatorów-monarchistów, zebranych na sejmie 1606 roku, były wyraźnym wsparciem dla królewskiej propozycji ${ }^{42}$. Często podkreślały niebezpieczeństwo zewnętrzne i groźbę wojny domowej. Jednak ciekawym, wyróżniającym się głosem na tle pozostałych monarchistów, było wotum biskupa łuckiego Marcina Szyszkowskiego. Mowa Szyszkowskiego wyróżniała się głównie tym, że stanowiła rzadki i odosobniony głos opowiadający się za jednostkowymi decyzjami $^{43}$, nie tylko na forum sejmu 1606 roku, ale w ogóle w czasach panowa-

38 „[...] wiele ich [posłów - aut.] najduje się, którzy w domach swych, co za konkluzye sejmikowe, a nie tylko sejmikowe, ale i sejmowe być mają, stanowią”, ibidem, s. 223. ibidem, s. 224.

39 „Naydują się i tacy, którzy „per opprobrium” o naszych sejmach komedye sobie czynią”,

40 Ibidem.

41 J. Maciszewski, Wojna domowa w Polsce..., s. 106.

42 W. Sobieski, Pamiętny sejm..., s. 75-98.

${ }^{4} \mathrm{~J}$. Urwanowicz, Ideologia a dziatalność polityczna szlachty w czasach Zygmunta III. Wokót wartości ustrojowych, [w:] Między monarchą a demokracją. Studia z dziejów Polski XV-XVIII wieku, red. A. Sucheni-Grabowska, M. Żaryn, Warszawa 1994, s. 179. 
nia Zygmunta III. Biskup otwarcie zaatakował opozycję, uznając ją za winną rozejścia się poprzedniego sejmu, skutkiem czego niegotową do obrony Rzeczpospolitą zaskoczył najazd tatarski ${ }^{44}$. Ściśle trzymał się instrukcji królewskiej, wskazując, że najpierw na sejmie trzeba omawiać sprawy najpilniejsze, a bez reformy prowadzenia sejmowej dyskusji niemożliwa jest reforma armii. Konieczna jest zmiana głosowania, gdyż „non maior et senior pars concludit, ale dwaj, albo trzej, co wszyscy uradzą, wszystko rozprószą" ${ }^{45}$. Szyszkowski był zatem zdecydowanym zwolennikiem zniesienia liberum veto. Jednocześnie biskup posuwał się aż do pochwały absolutum dominium, ustroju, który miał kiedyś panować w Rzeczpospolitej, z pożytkiem dla kraju i jego mieszkańców:

dawniej za przodków lepiej bywało, kiedy było absolutum dominium, kiedy kazał król wsiadać [na koń - przyp. W. Sobieski] wsiadali i straszni byli nieprzyjaciołom. Teraz inaczej, każdy o wolnościach gada ${ }^{46}$.

Przyznać trzeba Szyszkowskiemu wielką odwagę względem wypowiadanych poglądów. Sam zwrot absolutum dominium był dla szlachty polskiej obcy, nieprzyjemny, wypowiadany li tylko w negatywnym kontekście (oskarżenia króla i jego stronnictwa o chęć zaprowadzenia tejże formy ustrojowej w Polsce). Biskup łucki nie tylko użył go w pozytywnym kontekście (jako remedium na teraźniejsze problemy), ale również powołał się na rzekome funkcjonowanie absolutum dominium w Rzeczpospolitej. Jak zauważył Zbigniew Ogonowski, radykalne wypowiedzi polityczne, głoszące potrzebę przebudowy instytucji państwowych w kierunku gruntownego wzmocnienia władzy centralnej, odbierane były przez szlachecką opinię publiczną jako zdrada narodu i Rzeczpospolitej. Można było urządzenia ustrojowe Rzeczpospolitej krytykować, a nawet wyszydzać, wychwalanie jednak takiego programu reform groziło śmiercią polityczną ${ }^{47}$. Tak śmiałe sformułowanie postulatów wzmocnienia władzy królewskiej przez Szyszkowskiego mogło zatem przysporzyć królowi więcej przeciwników niż zwolenników, dać więcej szkody niż pożytku, szczególnie w dobie mocno zaognionej sytuacji politycznej w kraju.

44 W. Sobieski, Pamiętny sejm..., 80.

45 Ibidem, s. 82.

46 Ibidem.

47 Z. Ogonowski, Filozofia polityczna w Polsce XVII wieku i tradycje demokracji europejskiej, Warszawa 1992, s. 79-80. 
Jedną z najciekawszych, a zarazem najbardziej radykalną koncepcję wzmocnienia władzy w Rzeczpospolitej prezentuje Consilium na tryumfie krakowskim przy wróceniu się KJM z Janowca jemu dane napisane ${ }^{48}$. Utwór został napisany po ugodzie pod Janowcem między królem a rokoszanami, jednak jego autorstwo jest sporne. Zawarte w nim poglądy i przekonania oraz retoryka tekstu wskazują na zdeklarowanego monarchistę, stąd J. Maciszewski jego autorstwo przypisał referendarzowi koronnemu Feliksowi Kryskiemu ${ }^{49}$. Odmienne stanowisko prezentował $S$. Cynarski, uznając, że autor pisma był zapewne rokoszaninem, bo wypuszczenie takich treści tuż po zawartej ugodzie z grona monarchistów byłoby ciężkim błędem i dyskredytacją zamierzeń dworu ${ }^{50}$.

Consilium... postuluje dwie zasadnicze reformy, które autor uznawał za podstawę sprawnie funkcjonującego kraju. Pierwszą było zbudowanie pieniężnej potęgi państwa. Wzmocnienie skarbu koronnego winno odbyć się poprzez lustrację dóbr koronnych, przywrócenie ad primum statum ekonomii, z których to wówczas będzie można wyegzekwować kwartę ${ }^{51}$. Dodatkowych pieniędzy miałyby przysporzyć roczna intrata w pełnej wysokości z rozdanych wakancji, stały podatek nałożony na stan rycerski oraz zakaz oddawania duchownym annat do Rzymu ${ }^{52}$.

Druga kwestia służąca wzmocnieniu państwa i pozycji monarchy to konieczność zaprowadzenia „prędkiej rady”. Jądrem tej reformy byłoby całkowite zniesienie izby poselskiej jako organu opóźniającego uchwalanie ustaw, powodującego zamieszanie i będącego - według autora - novum w systemie ustrojowym, dodajmy, novum szkodliwym. Co znamienne, autor uznał, że senat przez wielką liczbę zasiadających tam dostojników także „confusio ex parte zostawa, a rady przez nię do skutku nie przychodzą" ${ }^{3}$. Dlatego liczba senatorów powinna być stopniowo i systematycznie ograniczana przez nierozdawanie stanowisk po zmarlych senatorach oraz swego rodzaju „wykańczanie” finansowe tych po-

48 Inna nazwa pisma to Victoria; Bibl. Kórn. PAN, sygn. 317, k. 65-66v; druk w: J. Czubek, Pisma polityczne..., t. 3, s. 181-185. W wydaniu Czubka oddzielono część zawierającą program reform - Compedium naprawy Rzpltej.

49 J. Maciszewski, Kryski Feliks..., s. 483.

50 S. Cynarski, Stronnictwo królewskie w dobie rokoszu Zebrzydowskiego..., s. 22.

51 Consilium..., [w:] Pisma polityczne..., t. 3, s. 182. Najpełniejsze omówienie koncepcji wyłożonych w Consilium... jak do tej pory przedłożył Janusz Byliński; J. Byliński, Antyregalistyczna propaganda w czasach rokoszu Zebrzydowskiego (1606-1608), [w:] Na obrzeżach polityki, cz. 1, red. M. Kosman, Poznań 2002, s. 23-25.

52 Consilium..., [w:] Pisma polityczne..., t. 3, s. 182.

53 Ibidem, s. 183. 
zostałych - wysyłanie ich w poselstwa i nakładanie na nich licznych posług wobec kraju. Takie działania stworzyłyby miejsce do powstania „rady komornej”, skupiającej ludzi godnych najwyższego zaufania.

Consilium... to nie tylko konkretne postulaty reformy, ale również krytyka dotychczasowego ustroju Rzeczpospolitej. Ustrój ten autor prezentuje z nieukrywanym lekceważeniem, a nawet pogardą. Rzeczpospolita to państwo, gdzie tot reges et leges, quot nobiles, „zuchwała licencya” wolności i swobód szlacheckich słusznie pozwala wołać, że „nierządem Polska stoi” ${ }^{4}$, skoro poddani rozkazują władcy, dyktują mu warunki i wysuwają wobec niego śmiałe żądania. Na szczęście nadszedł czas, kiedy możliwe są zmiany w duchu, czego autor nie ukrywa, absolutystycznym. Ideałem autora są państwa, gdzie władza monarchów „jest swobodna i w mocy ich położona”, a za przykład takiego państwa podaje Królestwo Niebieskie. Cechujące się rewolucyjnym radykalizmem ${ }^{55}$ Consilium... było wyrazem koncepcji przebudowy Rzeczpospolitej w duchu absolutystycznym. Korzyści z tego ustroju miał pokazać czas, a sam plan był bardzo dalekosiężny, bo zakładał panowanie jednego władcy nad całą Europą: „wszytkiej Europie jeden pan, a ledwie i nie wszytkiemu światu panować będzie" ${ }^{56}$. To fantastyczne i niemożliwe do realizacji założenie końcowe nie dezawuuje jednak całości wyłożonego w Consilium... programu reform.

Ugoda zawarta między królem a rokoszanami w październiku 1606 roku, choć pozwoliła uniknąć na pewien czas starcia zbrojnego, nie stanowiła przełomu w konflikcie. Przeciwnicy króla rychło podjęli ideę kontynuacji rokoszu, co dla stronników monarchy było niemiłym zaskoczeniem. Pod wpływem nacisków szlachty z początku 1607 roku, król zdecydował ostatecznie o zwołaniu tak wyczekiwanego sejmu na 7 maja 1607 roku. Ograniczenia, jakie na Zygmunta III i jego stronnictwo nałożyła ugoda janowiecka (a konkretnie przyjęte artykuły wiślickie i obietnica „porównania” ich z artykułami sandomierskimi rokoszan), w zasadzie przekreślały jakąkolwiek możliwość wzmocnienia władzy w trakcie jego obrad.

Instrukcja królewska na sejmiki przedsejmowe była więc, z racji wymienionych wyżej powodów, zachowawcza, a nawet wsteczna w stosunku do tej z 1606 roku $^{57}$. Król wyrażał chęć załagodzenia problemów i przywrócenia porządku w Rzeczpospolitej, wymieniał również te z artykułów wiślickich, które

54 Ibidem, s. 181.

55 J. Byliński, Antyregalistyczna propaganda..., s. 23.

56 Consilium..., [w:] Pisma polityczne..., t. 3, s. 185.

57 Instrukcja na sejm wraz z suplementum, AGAD, Zbiór Branickich z Suchej, 148/172, 
udało się już wprowadzić w życie, zdawał niejako sprawozdanie z tego, co zamierza uczynić w kwestii kolejnych. W przeciwieństwie do instrukcji z 1606 roku propozycja od tronu na sejm 1607 roku nie zawierała żadnych postulatów reform w duchu wzmocnienia władzy królewskiej. Delikatnie tylko próbowano wysondować szlachtę w kwestii jej poglądów na ewentualną wojnę z Moskwą (Zygmunt III podkreślał niestabilną sytuację tego państwa w związku z zabójstwem Dymitra, wymordowanie polskich obywateli i okazję do odebrania utraconych niegdyś prowincji), ale zapytanie miało bardzo zawoalowaną formę. Jak uznał J. Maciszewski, król w instrukcji przedstawiał się jako obrońca praw i wolności szlacheckich, a sejm jako konstytucyjny i jedyny legalny środek rozwiązania sporów przeciwstawił nielegalnym zjazdom szlacheckim ${ }^{58}$. Sytuacja w państwie była na tyle poważna, że w danym momencie wzmocnienie władzy królewskiej było niemożliwe.

Taki charakter instrukcji na sejmiki, same obrady sejmowe (na które w ogóle nie przybyli chociażby przedstawiciele województwa krakowskiego), odbywający się jednocześnie zjazd rokoszan w Jędrzejowie zdeterminowały przebieg sejmu, vota posłów i senatorów oraz uchwalone konstytucje. Prócz filozoficznego w zasadzie stwierdzenia wyrażającego poglądy na władzę, wygłoszonego przy witaniu króla przez marszałka sejmu Feliksa Kryskiego („powiadają politycy, że trudno ludźmi rządzić, a ja i o to przydam zwłaszcza wolnymi" ${ }^{9}$ ), większość wotujących zachowała daleko idącą powściągliwość. Może jedynie wojewoda poznański Hieronim Gostomski radził zastosować prawo silniejszego, bo „mowę swą interpretował, iż victor leges dabit, ukazował byczyńską wojnę, pojmano, pobrano etc., etc. A jednak ad absolut[um-aut.] $d\left[\right.$ omi-aut]nium nie przyszło" ${ }^{60}$. Prace posłów skoncentrowały się wokół nadania formy prawnej artykułom wiślickim i sandomierskim, a król przyjął pozycję wycofaną i oddającą w całości inicjatywę ustawodawczą izbie poselskiej, gdyż postanowił nie brać udziału w naradach publicznych ${ }^{61}$.

Choć Violetta Urbaniak zauważyła w układzie izby poselskiej i senatu przewagę sił prokrólewskich, stwarzającą możliwość realizacji własnych zamie-

s. 479-491; omówienie instrukcji: S. Łubieński, Rozruchy domowe w Polsce..., s. 130-134; H. Schmitt, Rokosz Zebrzydowskiego, Lwów 1858, s. 433-437.

58 J. Maciszewski, Sejm 1607 r. a zatamanie sięplanów reformy państwa..., s. 41.

59 Przemowa marszałka poselskiego [Feliksa Kryskiego], Bibl. Kórn. PAN, sygn. 318, k. $47 \mathrm{v}$.

${ }^{60}$ Diariusz sejmu 1607 roku, Riksarkivet Stockholm, Skokloster E 8599, k. 326.

${ }^{61}$ S. Łubieński, Rozruchy domowe w Polsce..., s. 135-136. 
rzeń przez Zygmunta III i podjęcia inicjatywy przez dwór ${ }^{62}$, to w praktyce sejmowej okazało się to niemożliwe. Jakakolwiek próba wyjścia poza artykuły wiślickie i sandomierskie odbierana była przez opozycyjnie nastawioną szlachtę, dodatkowo podburzaną przez stały kontakt z rokoszanami spod Jędrzejowa, jako próba wzmocnienia władzy królewskiej. Uchwalone konstytucje sejmowe wskazują na to, że król i monarchiści zostali zmuszeni do rezygnacji z planów reform ustrojowych, a uchwały sejmu 1607 roku były dla nich krokiem do tyłu.

Pierwszy artykuł był powtórzeniem dobrze znanego prawa, stanowiącego „źrenicę” wolności szlacheckich, mianowicie prawa wolnej elekcji. Pojawienie się ponownie tego punktu służyło li tylko obaleniu argumentu rokoszan oraz udowodnieniu mającej wątpliwości co do postępowania króla szlachcie, że Zygmunt III nie zamierza ani koronować królewicza Władysława za swojego życia ani nie proponuje tronu polskiego Habsburgom ${ }^{63}$. Uspokojeniu szlachty, że król nie snuje planów zaprowadzenia w Rzeczpospolitej absolutum dominium, służyła kolejna konstytucja - „O mieszkaniu senatorów”. Senatorowie rezydenci mieli zdawać sejmowi relację „o wszytkich sprawach publicznych, y Rzpltey należących, a pod mieszkanie przypadaiących"64. Kłam pogłoskom, że na władcę największy wpływ mają służący mu „złą radą” cudzoziemcy, miała położyć konstytucja „O cudzoziemcach”, zabraniająca im przebywać w otoczeniu króla (wyjąwszy paru Szwedów z konieczności zarządzania sprawami Królestwa Szwedzkiego) oraz sprawować w kraju urzędów czy otrzymywać nadania ${ }^{65}$. Te i inne konstytucje uchwalone na sejmie 1607 roku miały na celu udowodnić szlachcie, że Zygmunt III nie myśli o reformach w duchu absolutystycznym. Można więc śmiało uznać, że stanowiły one klęskę monarchistów.

Zwycięstwo króla w bitwie z rokoszanami pod Guzowem 5 VII 1607 roku nie wpłynęło na pojawienie się koncepcji wzmocnienia władzy w Rzeczpospolitej. Złożyły się na to rozmaite czynniki, a ich omówienie wykracza poza ramy tego artykułu. Wspomnę tylko, że pod Guzowem Zygmunt III i wierne $\mathrm{mu}$ stronnictwo nie walczyło o przeforsowanie zbudowanego przed sejmem 1606 roku projektu reform, ale o zachowanie całości władzy królewskiej po wypowiedzeniu władcy posłuszeństwa przez rokoszan 24 czerwca 1607 roku pod Jeziorną. I choć, jak już wyżej dowiedziono, w gronie stronników króla znajdowali się monarchiści, którym koncepcje wzmocnienia władzy w Rzecz-

\footnotetext{
${ }^{62}$ V. Urbaniak, Zamoyszczycy bez Zamoyskiego..., s. 100.

${ }^{63}$ Volumina Legum, t. 2, Petersburg 1859, s. 1596-1597.

${ }^{64}$ Ibidem, s. 1598.

${ }^{65}$ Ibidem, s. 1598-1599.
} 
pospolitej nie były niemiłe, to sam moment klęski rokoszan nie był czasem do tego korzystnym. Oznaczałoby to przede wszystkim dalszą walkę zbrojną z nierozbitym ostatecznie ugrupowaniem rokoszowym, walkę, dodajmy, bratobójczą, której, poza naprawdę nielicznymi, nikt w Rzeczpospolitej toczyć nie chciał. Zresztą sam Zygmunt III zdawał się nie widzieć w tym momencie lepszej drogi do uspokojenia kraju jak przystąpienie, oczywiście pod pewnymi warunkami, do rokowań pokojowych ${ }^{66}$.

Czy koncepcje wzmocnienia władzy politycznej w Rzeczypospolitej $\mathrm{w}$ dobie rokoszu sandomierskiego miały odzwierciedlenie w poezji politycznej tamtych czasów? Wydaje się, że główne ostrze piór poetów związanych z dworem skierowane zostało przeciwko zarzutom rokoszan wobec władcy i jego stronnictwa, było na nie odpowiedzią ${ }^{67}$. Inną grupę stanowią wiersze sławiące ugodę pod Janowcem ${ }^{68}$, kolejną - utwory o charakterze parodystycznym i satyrycznym ${ }^{69}$. Brak wierszy stricte wykładających program stronnictwa prokrólewskiego. Tylko w niektórych utworach dostrzec można sugestie, że wzmocnienie władzy w Polsce byłoby procesem korzystnym. Takie aluzje zawiera Wyznanie urazów prawdziwych ślachcica polskiego ${ }^{70}$. Anonimowy autor przyczynę jednego z problemów, jakim jest zaniedbanie obrony kraju, widzi w tym, że dochody płyną do prywatnych kieszeni zamiast do skarbca królewskiego. To jedno ze źródeł słabości króla, któremu po prostu brak pieniędzy:

Bo zaż to słuszność, aby was królowie

Bronili, którym pobrali panowie

To wszystko, skąd was bronić kiedy mieli ${ }^{71}$.

${ }^{66}$ Zygmunt III do Mikołaja Krzysztofa Radziwiłła, X 1607, AGAD, AR, dz. II, nr 529, s. 1.

${ }_{67}$ Taki charakter mają na przykład utwory Apologia na paskwil autorstwa Kaspra Miaskowskiego, [w:] Pisma polityczne z czasów rokoszu Zebrzydowskiego 1606-1608, t. 1: Poezya rokoszowa, wyd. J. Czubek, Kraków 1916, s. 24-33 czy anonimowo wydany utwór Jana Żabczyca Nie masz króla - jest, bm. 1607. Omówienie utworów: J. Nowak-Dłużewski, Okolicznościowa poezja polityczna $w$ Polsce. Zygmunt III, Warszawa 1971, s. 124, 150-152.

68 Przykładem są tu Pieśń po rokoszu a. 1606 oraz Druga pieśń o rokosie, [w:] Pisma polityczne..., t. 1, s. 125-127. Omówienie utworów: J. Nowak-Dłużewski, Okolicznościowa poezja polityczna $w$ Polsce..., s. 138.

69 Chociażby Passya pana naszego Zygmunta Trzeciego, króla polskiego, podtug jego stugi i wiernego poddanego, z panem swym wspótcierpiącego autorstwa Szczęsnego Kryskiego, [w:] Pisma polityczne..., t. 2, s. 51-56. Omówienie: J. Nowak-Dłużewski, Okolicznościowa poezja polityczna w Polsce..., s. 138-140.

70 Pisma polityczne..., t. 1, s. 5-10.

${ }^{71}$ Ibidem, s. 8. 
Autor buntuje się przeciwko panującym porządkom, gdzie możni panowie znaczą więcej niż dany od Boga władca:

Azaż to grzeczy, że więcej ważycie

Pany prywatne, które złe baczycie,

Niźliże króla, od Boga danego

A od nich prawie samych zdradzonego ? $^{72}$

Słabość Rzeczpospolitej anonim dostrzega głównie w tym, że kompetencje niegdyś przynależne władcy przechodzą w ręce panów:

Nie mamy pana, bo oni królami

Chcą być koniecznie, oni urzędami

Chcą i sędziami, a gdy, co chcą, czynią,

Sami to przecię króla we wszem winią ${ }^{73}$.

Wyznanie urazów... stanowi w zasadzie jedyny utwór poezji doby rokoszu, gdzie w zawoalowany, niezwykle delikatny sposób odnotowano, że wzmocnienie władzy jest remedium na teraźniejsze problemy Rzeczpospolitej.

$\mathrm{Na}$ zakończenie wypada jeszcze poświęcić parę słów na temat losów $\mathrm{Ka}$ zania VI Piotra Skargi. Jego dzieje są niejako miernikiem wykonalności i popularności koncepcji wzmocnienia władzy w kraju. Kazania sejmowe zostały wydane w 1597 roku, ich dokładny przedruk ukazał się ponownie trzy lata później. Piotr Skarga, zwany przez rokoszan praecipuus turbator Reipublicae, był jednym z najzagorzalszych zwolenników wzmocnienia władzy monarszej w stronnictwie Zygmunta III. Jedną z głównych przyczyn słabości Rzeczpospolitej jezuita widział w ograniczeniu władzy królewskiej. Nieraz wyrażał pogląd, że władza ustawodawcza izby poselskiej stwarza niebezpieczeństwo dla państwa, gdyż jest wynikiem samowolnego rozszerzenia się przywilejów szlacheckich, a brak kwalifikacji posłów nie pozwala uporać się z poważnymi obowiązkami państwowymi ${ }^{74}$. Skarga zwracał uwagę na wiedzę i doświadczenie senatorów w przeciwieństwie do izby poselskiej. Uważał, że większość przywilejów szlacheckich należy szlachcie odebrać, a udział szlachty w wolnej elekcji

72 Ibidem, s. 8.

73 Ibidem, s. 10.

${ }^{74}$ J. Tazbir, Wstęp, [w:] P. Skarga, Kazania sejmowe, opr. J. Tazbir przy współudziale M. Korolki, Wrocław 2008, s. LXII-LXIII. 
to akt całkowicie bezprawny, bo król władzę otrzymuje od Boga, za pośrednictwem kapłana ${ }^{75}$.

Program polityczny wyrażony w Kazaniach... Skargi był nie tylko radykalny, ale również utopijny. Po pierwsze, za postulatami zaprowadzenia w Polsce absolutyzmu nie szły metody, jakimi miałoby się to dokonać, po wtóre autor uważał poniekąd, że tak rewolucyjne reformy uda się zaprowadzić w państwie na drodze pokojowej, a szlachta sama zrzeknie się wywalczonych wcześniej przywilejów. Nie wydaje się, aby szlachta poważnie podchodziła do koncepcji zawartych w dziele królewskiego kaznodziei, gdyż krytyka poglądów Skargi znalazłaby wówczas żywe odbicie w publicystyce rokoszowej, tak zaś się nie stało ${ }^{76}$.

Warto zwrócić natomiast uwagę, że w kolejnym wydaniu Kazań... z 1610 roku zabrakło Kazania VI: O monarchijej i królestwie, abo o czwartej chorobie Rzeczypospolitej, która jest z ostabienia królewskiej dostojności i wtadzej, natomiast fragmenty krytykujące osłabienie władzy królewskiej w pozostałych kazaniach zostały zmodyfikowane lub usunięte. Wynikało to prawdopodobnie z tego, że ruch rokoszowy ujawnił z całą mocą sprzeciw, jaki żywiły rzesze szlacheckie przeciw jakimkolwiek planom wzmocnienia władzy królewskiej. Zakon jezuitów uznał zatem za stosowne wycofanie się z poparcia takich planów, skutkiem czego było okrojenie trzeciego wydania dzieła ${ }^{77}$. Stąd konkluzja, że choć powstanie kazań nie miało miejsca w czasie trwania rokoszu, to wykreślenie Kazania VI i modyfikacja pozostałych jest już jak najbardziej skutkiem rokoszu sandomierskiego.

Społeczeństwo szlacheckie u progu XVII wieku było niechętne zmianom ustrojowym prowadzącym do wzmocnienia władzy królewskiej w Rzeczpospolitej. Samo sformułowanie absolutum dominium stanowiło swego rodzaju hasło-straszak, znienawidzony synonim tyraństwa, podeptanych praw i wolności, hasło, po które - co interesujące - często i namiętnie sięgaty obie strony konfliktu - zarówno rokoszanie (oskarżając władcę o próby zaprowadzenia tego ustroju w Polsce), jak i monarchiści (zarzucający rokoszanom, że narzucają siłą swoją wolę większości przez chociażby bezprawną detronizację władcy). Spowodowało to, że wszelkie nurty myśli propagującej koncepcje absolutyzmu były w Rzeczpospolitej wątłe, a jeśli już ujawniane, to w sposób niezwykle ostrożny ${ }^{78}$.

\footnotetext{
75 Ibidem, s. LXIII-LXV.

76 Idem, Skarga Piotr..., s. 39-40.

77 Ibidem, s. 41.

${ }^{78}$ Z. Ogonowski, Filozofia polityczna w Polsce XVII wieku..., s. 147-148.
} 
Jak wykazał już Janusz Byliński, stronnictwo rokoszan nie zaproponowało reform ustrojowych, a tylko skupiło się na powtarzaniu zarzutów wobec Zygmunta III (nierozdawanie wakancji, przebywanie na dworze królewskim cudzoziemców, kwestia kurateli pruskiej itp.). Rokoszanie przygotowali w zasadzie dla władcy pakiet żądań ${ }^{79}$, licząc na to, że król zgodzi się na ich przyjęcie.

Wszystko wskazuje na to, że stronnictwo prokrólewskie względem reform ustrojowych wykazało o wiele dalej idącą inicjatywę. Przykładem tego są wyżej wymienione i przeanalizowane koncepcje reform w duchu wzmocnienia władzy z dwoma najważniejszymi pomysłami - jednym wysuniętym przed sejmem 1606 roku, drugim - po ugodzie pod Janowcem, zawartym w Consilium.... O ile program wyłożony w Consilium... w rzeczywistości ustrojowej Rzeczpospolitej XVII wieku słusznie odebrać można jako radykalny czy nawet rewolucyjny i przez to nie mający najmniejszych szans na realizację ${ }^{80}$, to, moim zdaniem, postulaty reform przygotowane przed sejmem 1606 roku uznać należy za wyważony, realny, nieznaczny krok na drodze wzmocnienia władzy królewskiej. Przedstawiony w innych okolicznościach niż rozgorączkowana, roznamiętniona przez rokoszowych podżegaczy atmosfera przedsejmowa 1606 roku, miał szansę trafić na podatniejszy grunt i zostać, choć częściowo, zrealizowany.

\title{
The program of reinforcing the royal supporters during Sandomierz Rebellion 1605-1609 (Sandomierz Rebellion; in Polish: rokosz - semi-legal rebellion)
}

\author{
(Summary)
}

This article strives to present reforms prepared by king's Sigismund III Vasa supporters as faced with Sandomierz Rebellion (rokosz sandomierski). The king's opposition focused mostly on critique and accusations of the monarch, rather than constructing one compact program of political reforms. The royalists' camp appeared far more proactive with their ideas of constitutional reforms.

The first idea, whose goal was to reform the Polish-Lithuanian Commonwealth and to strengthen king's role in the government, was presented to the nobles before the Parliament session in 1606. It involved a long-term project of introducing fixed taxes, which were supposed to finance the maintenance of a professional army. It also dealt

\footnotetext{
79 J. Byliński, Rokoszowe koncepcje reformy państwa..., s. 92.

80 Idem, Antyregalistyczna propaganda..., s. 25.
} 
with the issue of regaining the Swedish throne. The king demanded that the Parliament should debate on the royal propositions only, fearing that including the nobility's demands would result in breaking up the session, but his postulate was refused. The commentary to king's instructions was embodied in a paper entitled Votum szlachcica polskiego pisane na sejmiki i sejm roku pańskiego 1606, which undoubtedly originated in the camp of royal supporters. A thorough analysis shows that the document proposed even bolder projects of reforming the army and the Parliament than those proposed by the king.

One of the most interesting, and at the same time radical concepts of strengthening the monarchy can be found in the Consilium na tryumfie krakowskim przy wróceniu sie $K J M z$ Janowca jemu dane napisane. It was written after the agreement that the king and the rebellious nobles had come to in 1606 in Janowiec. The document postulates two major reforms, that were considered by the author to be vital in reviving the country. The first one was supposed to build financial power of the Commonwealth by introducing fixed taxes for nobility and payments for the titles given by the king. The other issue, crucial for strengthening the country and empowering the king, was the necessity to dismiss the Chamber of Deputies as it was only causing chaos and paralyzing the proceedings. The author considered the Chamber of Deputies to be nothing more but an unnecessary novelty in the political system. As for the senators, he proposed that their number should be gradually decreased. Those actions were supposed to set the stage for a new organ, a "chamber council", which would include only the most trusted of king's men.

In the beginning of the $17^{\text {th }}$ century the privileged noble class was not willing to allow for systemic changes that would empower the monarchy in the Commonwealth. The phrase absolutum dominium alone, was a loathed synonym of tyranny and violation of laws and freedom. That is the reason why the radical project of reforms described in Consilium... did not stand a chance of success in the Commonwealth. Propositions that were presented to the Parliament in 1606 on the other hand, should be considered as a realistic and balanced step to empower the monarchy. Had they been presented in other circumstances than the emotional and rebellious atmosphere before the parliament session in 1606, they might have been adopted, at least partially.

Agnieszka Pawłowska, doktorantka w Instytucie Historii i Archiwistyki UMK agnieszkapawl@wp.pl 